\title{
PENGARUH KUALITAS PELAYANAN LOKET PENDAFTARAN TERHADAP KEPUASAN MASYARAKAT DI KANTOR PERTANAHAN KABUPATEN BOGOR
}

\author{
${ }^{1)}$ Muhlis, ${ }^{2)}$ Dinar Rahmania \\ ${ }^{1)}$ Dosen Program Studi Manajemen, STIE Dewantara \\ Jl. Raya Pemda Bojong Depok Baru III, Karadenan, Cibinong, Bogor, Jawa Barat 16913, Indonesia \\ Email: muhlis@dewantara.ac.id \\ ${ }^{2)}$ Alumni Program Studi Manajemen, STIE Dewantara \\ Jl. Raya Pemda Bojong Depok Baru III, Karadenan, Cibinong, Bogor, Jawa Barat 16913, Indonesia \\ Email: dinarrahmania290797@gmail.com
}

\begin{abstract}
The purpose of this study was to determine the effect of reliability, responsiveness, assurance, attention, and physical evidence on community satisfaction partially or simultaneously. The method of collecting data for testing hypotheses using filling in questionnaires aimed at 100 respondents of people over the age of 17 who use the services at the registration counter.The results of multiple linear analysis show that the influence of service quality dimensions is $R 2=$ 0.346, which means that the contribution of variable $X$ (Service Quality) plays a role in influencing the $Y$ variable (Community Satisfaction) of 34.6\%. Based on the results of the test the responsiveness and attention variables influence people's satisfaction. Judging from the results of the test $f$ community satisfaction together is influenced by variables of reliability, responsiveness, assurance, attention, and physical evidence at the level of alpha significance of $10 \%$ or $90 \%$ confidence level. Based on the results of the t test the responsiveness and attention variables influence people's satisfaction.
\end{abstract}

Keywords: Service Quality, Community Satisfaction, Public Service, Land Office, Bogor Regency.

ABSTRAK
Tujuan penelitian ini untuk mengetahui pengaruh keandalan, daya tanggap, jaminan, perhatian, dan bukti fisik terhadap kepuasan masyarakat secara parsial maupun simultan. Metode pengumpulan data untuk pengujian hipotesis menggunakan pengisian kuisioner yang ditujukan 100 responden masyarakat berusia di atas 17 tahun yang menggunakan pelayanan di loket pendaftaran. Hasil analisis linear berganda bahwa dapat diketahui pengaruh dimensi kualitas pelayanan sebesar R2 =0,346 hal ini berarti sumbangan variabel $\mathrm{X}$ (Kualitas Pelayanan) berperan dalam mempengaruhi variabel $\mathrm{Y}$ (Kepuasan Masyarakat) Sebersar 34,6\%. Berdasarkan hasil uji t variabel daya tanggap dan perhatian berpengaruh terhadap kepuasan masyarakat. Dilihat dari hasil uji f kepuasan masyarakat secara bersama-sama dipengaruhi oleh variabel keandalan, daya tanggap, jaminan, perhatian, dan bukti fisik pada tingkat signifikansi alpha $10 \%$ atau tingkat kepercayaan $90 \%$. Berdasarkan hasil uji $\mathrm{t}$ variabel daya tanggap dan perhatian berpengaruh terhadap kepuasan masyarakat.

Kata kunci: Kualitas Pelayanan, Kepuasan Masyarakat, Pelayanan Publik, Kantor Pertanahan, Kabupaten Bogor.

\begin{tabular}{|c|c|}
\hline $\begin{array}{ll}1 . & \text { PENDAHULUAN }\end{array}$ & masyarakatnya dalam \\
\hline 1.1 Latar Belakang & pertanahan, \\
\hline Wilayah Kabupaten Bogor memiliki & mempunyai lembaga non kementrian yang \\
\hline luas tanah sekitar 298.838,31 Ha. Dengan & mengurusi pertanahan di Indonesia \\
\hline wilayah lahan yang begitu luas pemerintah & Badan Pertanahan Nasional (BPN). \\
\hline mewajibkan masyarakatnya untuk memiliki & Untuk menjalankan tugas dan fungsi \\
\hline $\begin{array}{l}\text { sertifikat tanah sebagai bukti kepemilikan } \\
\text { tanah yang sah dan di akui negara. Demi }\end{array}$ & $\begin{array}{l}\text { Badan Pertanahan Nasional (BPN) di } \\
\text { daerah, maka dibentuk kantor Wilayah BPN }\end{array}$ \\
\hline
\end{tabular}


di provinsi dan Kantor Pertanahan di Kabupaten/kota. Kantor pertanahan Kabupaten Bogor adalah lembaga yang mengurusi bidang pertanahan di Kabupaten Bogor mulai dari pendaftaran hingga penerbitan sertifikat serta mengurusi persengketaan tanah yang terjadi di masyarakat. Penelitian ini dilatarbelakangi dengan banyaknya fenomena mengenai kualitas pelayanan di bagian loket pendaftaran pertanahan di Kantor Pertanahan Kabupaten Bogor yang secara umum masih terdapat beberapa kelemahan.

Demi terwujudnya kepuasan masyarakat terhadap pelayanan publik maka seharusnya terpenuhi 5 (lima) aspek pelayanan yaitu, Tangible (Bukti fisik), Emphaty (Perhatian), Reliability (Keandalan), Responsive (Daya Tanggap), dan Assurance (Kepastian).

Loket pendaftaran pertanahan merupakan tempat dimana masyarakat ingin mendaftarkan tanah untuk diterbitkan sertifikatnya, petugas-petugas loket inilah yang memberikan pelayanan mengenai pendaftaran tanah untuk masyarakat di Kabupaten Bogor. Maka dari itu penelitian mengenai kualitas pelayanan loket pendaftaran sangatlah penting, dimana loket pendaftaran merupakan garda awal masyarkat mendapatkan pelayanan pertanahan sebelum ke pelayanan lainnya. Berdasarkan latar belakang tersebut, maka peneliti melakukan penelitian yang berjudul "Pengaruh Kualitas Pelayanan Loket Pendaftaran Terhadap Kepuasan Masyarakat di Kantor Pertanahan Kabupaten Bogor".

\subsection{Rumusan Masalah}

1. Apakah keandalan berpengaruh terhadap kepuasan masyarakat dalam pelayanan loket pendaftaran?

2. Apakah daya tanggap berpengaruh terhadap kepuasan masyarakat dalam pelayanan loket pendaftaran?

3. Apakah jaminan berpengaruh terhadap kepuasan masyarakat dalam loket pendaftaran?

4. Apakah perhatian berpengaruh terhadap kepuasan masyarakat dalam loket pendaftaran?

5. Apakah bukti fisikberpengaruh terhadap kepuasan masyarakat dalam loket pendaftaran?

6. Apakah keandalan, daya tanggap, jaminan, perhatian, dan bukti fisik berpengaruh secara bersamaan terhadap kepuasan masyarakat dalam loket pendaftaran?

\subsection{Tujuan Penelitian}

1. Untuk mengetahui dan menganlisis pengaruh keandalan terhadap kepuasan masyarakat dalam pelayanan loket pendaftaran.

2. Untuk mengetahui dan menganalisis pengaruh daya tanggap terhadap kepuasan masyarakat dalam pelayanan loket pendaftaran.

3. Untuk mengetahui dan menganalisis pengaruh jaminan terhadap kepuasan masyarakat dalam pelayanan loket pendaftaran.

4. Untuk mengetahui dan menganalisis pengaruh perhatian terhdap kepuasan masyarakat dalam pelayanan loket pendaftraan.

5. Untuk mengetahui dan menganalisis pengaruh bukti fisik terhadap kepuasan masyarakat dalam pelayanan loket pendaftaran.

6. Untuk mengetahui dan menganalisis pengaruh keandalan, daya tanggap, jaminan, perhatian, dan bukti fisik secara bersamaan terhdapa kepuasan masyarakat dalam pelayanan loket pendaftaran.

\section{TINJAUAN PUSTAKA}

2.1 Landasan Teori

\subsubsection{Kualitas Pelayanan}

Kualitas jasa atau layanan itu sendiri harus dimulai dari kebutuhan pelanggan 
dan berakhir dengan kepuasan pelanggan serta persepsi positif terhadap kualitas jasa atau layanan (Kotler dan Keller, 2012).

\subsubsection{Kualitas Pelayanan Publik}

Menurut UU No.25 Tahun 2009, yang dimaksud dengan pelayanan publik adalah kegiatan dalam rangka pemenuhan kebutuhan pelayanan sesuai dengan peraturan perundang-undangan bagi setiap warga negara dan penduduk atas barang dan jasa, dan atau pelayanan administrasi yang disediakan oleh penyelenggara pelayanan publik. Asas Pelayanan Publik Sinambela (2008:6) secara teoritik menjelaskan tujuan pelayanan publik pada dasarnya adalah memuaskan masyarakat.

\subsubsection{Kepuasan}

Menurut Zeithaml dan Bitner (2004 : 86) "Satisfaction is the customer's evaluation of a product or service in terms of whether that product or service has met their needs and expectation". Engel (dalam Tjiptono 2016:151) mengungkapkan bahwa kepuasan pelanggan merupakan evaluasi purna beli yang mana alternatif yang dipilih sekurang-kurangnya memberikan hasil (outcome) sama atau melampaui harapan pelanggan, sedangkan ketidakpuasan timbul apabila hasil yang diperoleh tidak memenuhi harapan pelanggan.

\subsubsection{Kepuasan Masyarakat}

Kepuasan adalah perasaan senang atau kecewa seseorang yang timbul karena seseorang yang timbul karena membandingkan kinerja yang dipersepsikan produk atau jasa terhadap ekspektasi mereka (Kotler, 2012). Lebih lanjut dalam Keputusan Menteri Pendayagunaan Aparatur Negara (KEPMENPAN) Nomor 25 Tahun 2004 Tentang Pedoman Umum Penyusunan Indeks Kepuasan Masyarakat Unit Pelayanan Instansi Pemerintah menyebutkan, "Sasaran dari Indeks Kepuasan Masyarakat adalah tingkat pencapaian kinerja unit pelayanan instansi pemerintah dalam memberikan pelayanan kepada masyarakat".

\subsection{Kerangka Pemikiran}

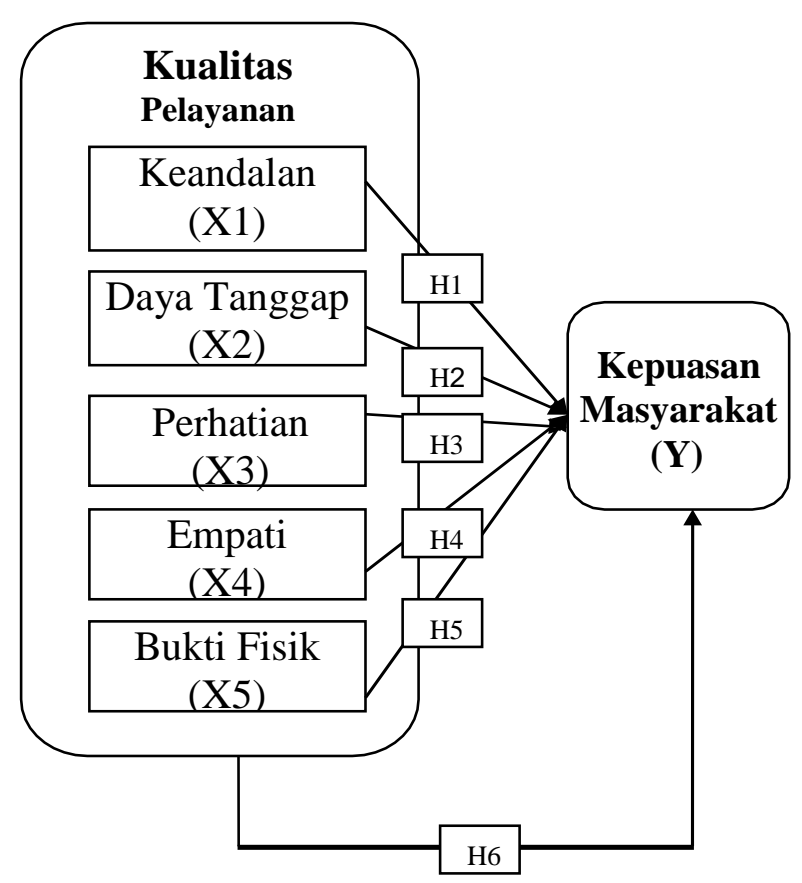

\section{Gambar 1. Kerangka Pemikiran}

\subsection{Definisi Operasional}

Berikut definisi operasional variabel akan dijelaskan pada tabel 1 .

\section{Tabel 1. Definisi Operasional}

\begin{tabular}{|c|c|l|c|}
\hline No & Variabel & Indikator & $\begin{array}{c}\text { Butir } \\
\text { Pertanya } \\
\text { an }\end{array}$ \\
\hline 1. & $\begin{array}{c}\text { Keandalan } \\
\text { (X1) }\end{array}$ & $\begin{array}{l}\text { - } \begin{array}{l}\text { Pegawai loket } \\
\text { menjelaskan } \\
\text { persyaratan- } \\
\text { persyaratan } \\
\text { pendaftaran } \\
\text { tanah sesuai } \\
\text { kebutuhan. } \\
\text { - }\end{array} \\
\text { Kemudahan } \\
\text { prosedur } \\
\text { pelayanan. } \\
\text { Kepastian } \\
\text { biaya } \\
\text { pelayanan. }\end{array}$ & 2 \\
\hline - Daya tanggap & 4 \\
\hline
\end{tabular}




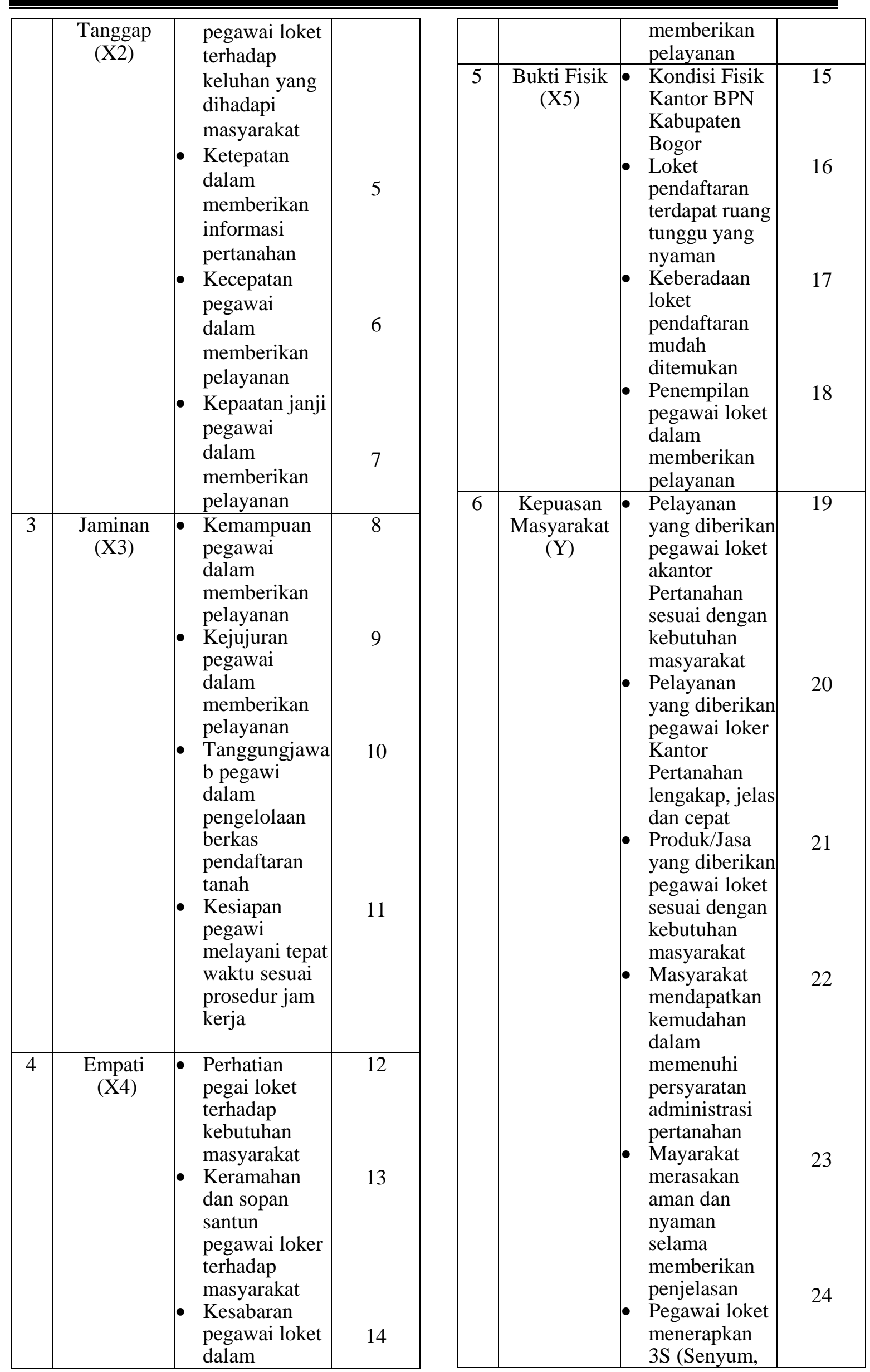




\section{Sapa, Salam)}

\section{METODE PENELITIAN}

\subsection{Jenis Penelitian}

Dilihat dari segi pendekatan yang digunakan maka jenis penelitian yang digunakan adalah penelitian kuantitatif yang bersifat kausal. Analisis kuantitatif menekankan pada pengujian teori melalui pengukuran variabel penelitian dengan angka dan melakukan analisis data dengan prosedur statistik. Penelitian kuantitatif adalah penelitian yan meneliti pengaruh dua variabel atau lebih.

\subsection{Variabel Penelitian}

Variabel yang digunakan dalam penelitian ini terdiri dari variable terikat (Y) dan variable bebas $(\mathrm{X})$ :

1. Variabel terikat dalam penelitian ini adalah kepuasan masyarakat di Kantor Pertanahan Kabupaten Bogor (Y).

2. Variabel bebas dalam penelitian ini yaitu kualitas pelayanan (X) yang terdiri dari Keandalan (X1), daya tanggap (X2), jaminan (X3), empati (X4), dan Bukti fisik (X5).

\subsection{Objek Penelitian}

Objek penelitian merupakan permasalahan yang diteliti, dalam penelitian iniyang menjadi objek penelitian adalah masyarakat yang menggunakan pelayanan publik pendaftaran tanah di Kantor Pertanahan Kabupaten Bogor.

\subsection{Lokasi dan Waktu Penelitian}

Lokasi penelitian ini adalah di Kantor Pertanahan Kabupaten Bogor yang beralamat di Jl. Tegar Beriman, Pakansari, Cibinong, Bogor. Adapun waktu penelitian ini dilaksanakan selama satu bulan pada bulan Agustus-September 2018.

\subsection{Populasi dan Sampel}

\subsubsection{Populasi}

Populasi dalam penelitian ini adalah masyarakat yang berusia diatas 17 tahun dan mendapatkan pelayanan di loket Kantor Pertanahan Kabupaten Bogor. Dalam satu hari masyarakat yang dilayani \pm 125 orang dan dikalikan selama 20 hari masa kerja jadi terdapat 2.500 populasi dalam penelitian ini.

\subsubsection{Sampel}

Menurut sugiyono (2013:118). "Sampel adalah Bagian dari jumlah karakteristik yang dimiliki oleh populasi tersebut'.Penentuan ukuran sampel dalam penelitian ini menggunakan rumus sebagai berikut :

$$
n=\frac{N}{1+e^{2}}
$$

$$
\begin{aligned}
& \text { Keterangan : } \\
& \mathrm{n}= \text { ukuran sampel } \\
& \mathrm{N}= \text { ukuran populasi (Dalam satu hari } \\
& \text { masyarakat yang dilayani } \pm 125 \\
& \text { orang dan dikalikan selama } 20 \\
& \text { hari masa kerja jadi terdapat } \\
& 2.500 \text { populasi dalam penelitian } \\
& \text { ini). } \\
& e^{2}= \text { kelonggaran ketidaktelitian } \\
& \text { karena kesalahan pengambilan } \\
& \text { sampel yang dapat ditolerir. }
\end{aligned}
$$

Dalam penelitian ini e ditetapkan sebesar $10 \%$.

Adapun perhitungan penentuan sampel dalam penelitian ini adalah sebagai berikut:

$$
\begin{aligned}
n & =\frac{N}{1+e^{2}} \\
& =\frac{2.500}{1+2.500(0,1)^{2}} \\
& =99,96 \text { dibulatkan menjadi } 100 .
\end{aligned}
$$

Jadi, sampel yang digunakan dalam penelitian ini adalah 100 responden.

\subsection{Teknik Sampling}

Teknik sampling yang digunakan dalam penelitian ini adalah non probability sampling. 


\subsection{Teknik Analisis Data}

Dalam penelitian ini menggunakan teknik analisis data, diantaranya :

1. Uji Validitas

2. Uji Reliabilitas

3. Uji Normalitas

4. Uji Multikolineritas

5. Uji Heterokedastisitas

6. Analisis Regresi Linier Berganda

7. Uji Signifikansi Parsial (Uji t)

8. Uji Signifikansi Silmutan (Uji F)

9. Koefisien Determinasi

\section{HASIL DAN PEMBAHASAN}

\subsection{Uji Validitas}

Uji Validitas digunakan untuk mengukur validnya suatu kuisioner. Dalam penentuan layak atau tidaknya suatu item yang digunakan, dilakukan uji signifikansi koefisien korelasi pada taraf signifikansi 0,1 , dan df -100 .

Berdasarkan hasil pengujian validitas keandalan, daya tanggap, jaminan, perhatian, bukti fisik, dan kepuasan masyarakat dinyatakan valid.

\subsection{Uji Reliabilitas}

Pengujian reliabilitas dalam penelitian ini dilakukan dengan menghitung besarnya nilai Croncbach's Alpha Instrumen dari masing-masing lima dimensi yang diuji. Apabila nilai Cronbach's Coefficient Alpha lebih besar dari 0,6 maka jawaban dari pada responden pada kuisioner sebagai alat pengukur dinilai dinyatakan reliable Program SPSS memberikan fasilitas untuk reliabilitas dengan uji statisti Cronbach Alpha $(\alpha)$.

Tabel 2. Hasil Uji Reliabilitas

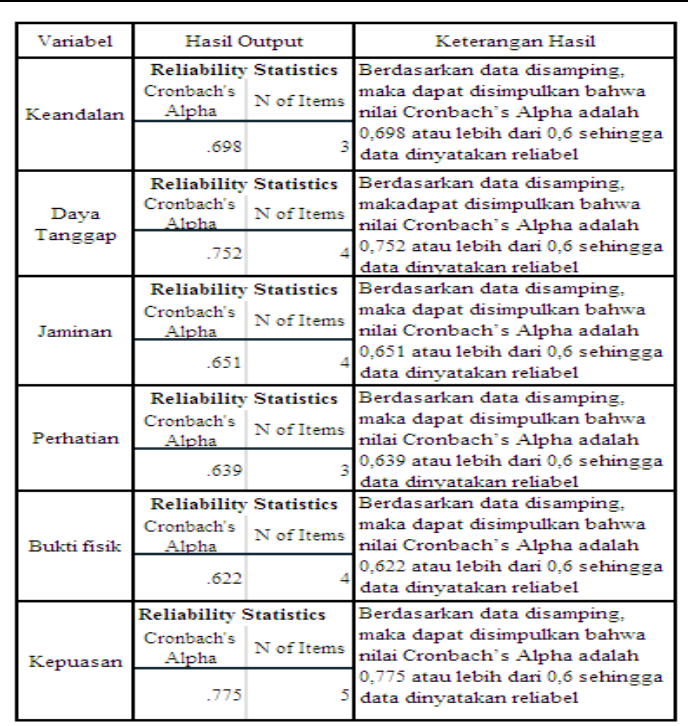

Sumber : Hasil Penelitian,2019 (data diolah)

\subsection{Uji Normalitas}

Dalam penelitian ini uji normalitas dilakukan dengan metode Uji Kolmogrov Smirnov dengan bantuan SPSS. Dengan adanya tes normalitas maka hasil penelitian bisa digeneralisasikan pada populasi. Dalam pandangan statistik itu sifat dan karakteristik populasi adalah terdistribusi secara normal.

\section{Tabel 3. Hasil Uji Normalitas}

\begin{tabular}{|c|c|c|}
\hline \multicolumn{3}{|c|}{ One-Sample Kolmogorov-Smirnov Test } \\
\hline & & $\begin{array}{c}\text { Unstandardize } \\
\text { d Residual }\end{array}$ \\
\hline \multicolumn{2}{|l|}{$\mathrm{N}$} & 100 \\
\hline \multirow{2}{*}{$\begin{array}{l}\text { Normal } \\
\text { Parameters }\end{array}$} & Mean & .0000000 \\
\hline & $\begin{array}{l}\text { Std. } \\
\text { Deviation }\end{array}$ & 1.69367975 \\
\hline \multirow{3}{*}{$\begin{array}{l}\text { Most Extreme } \\
\text { Differences }\end{array}$} & Absolute & .071 \\
\hline & Positive & .046 \\
\hline & Negative & -.071 \\
\hline \multicolumn{2}{|l|}{ Test Statistic } & .071 \\
\hline \multicolumn{3}{|c|}{$\begin{array}{l}\text { Asymp. Sig. (2-tailed) } \\
\text { a. Test distribution is Normal. } \\
\text { b. Calculated from data. } \\
\text { c. Lilliefors Significance Correction. } \\
\text { d. This is a lower bound of the true significance. }\end{array}$} \\
\hline
\end{tabular}


Berdasarkan data di atas, maka dapat dilihat bahwa nilai dari Asymp. Sig. (2tailed) adalah 0,2 atau diatas 0,1 . Berdasarkan hasil tersebut maka dapat dinyatakan bahwa data terdistribusi normal.

\subsection{Uji Multikolineritas}

Tabel 4. Hasil Uji Multikolineritas

\begin{tabular}{|c|c|c|c|c|c|c|c|c|}
\hline \multicolumn{9}{|c|}{ Coefficients $^{a}$} \\
\hline \multirow{2}{*}{\multicolumn{2}{|c|}{ Model }} & \multicolumn{2}{|c|}{$\begin{array}{l}\text { Unstandardize } \\
\text { d Coefficients }\end{array}$} & \multirow{2}{*}{$\begin{array}{c}\begin{array}{c}\text { Standar } \\
\text { dized } \\
\text { Coeffici } \\
\text { ents }\end{array} \\
\text { Beta }\end{array}$} & \multirow{2}{*}{$\mathrm{t}$} & \multirow{2}{*}{ Sig. } & \multicolumn{2}{|c|}{$\begin{array}{l}\text { Collinearity } \\
\text { Statistics }\end{array}$} \\
\hline & & B & $\begin{array}{l}\text { Std. } \\
\text { Error }\end{array}$ & & & & $\begin{array}{c}\begin{array}{c}\text { Tolera } \\
\text { nce }\end{array} \\
\end{array}$ & VIF \\
\hline \multirow{6}{*}{1} & (Constant) & 5.664 & 2.238 & & 2.531 & .013 & & \\
\hline & Keandalan & .075 & .180 & .048 & .417 & .677 & .505 & 1.980 \\
\hline & \begin{tabular}{|l|} 
Daya \\
Tanggap
\end{tabular} & .292 & .143 & .252 & 2.047 & .043 & .434 & 2.302 \\
\hline & Jaminan & .110 & .164 & .076 & .669 & .505 & .517 & 1.936 \\
\hline & Perhatian & .431 & 199 & 240 & 2.168 & .033 & .538 & 1.859 \\
\hline & Buktti Fisik & .182 & .143 & .132 & 1.270 & .207 & .610 & 1.639 \\
\hline
\end{tabular}

Sumber: Hasil Penelitian 2019 (data diolah)

Berdasarkan data di atas, maka dapat disimpulkan bahwa tidak ada nilai Tolerance dari keandalan,daya tanggap, jaminan, perhatian, dan bukti fisik yang kurang dari 0,1 dan nilai VIF dari keandalan, daya tanggap, jaminan, perhatian dan Bukti fisik yang lebih dari 10 . Berdasarkan hasil tersebut maka dapat dinyatakan bahwa data terhindar dari multikolinearitas.

\subsection{Hasil Uji Heterokedastisitas}

Uji

heterokedastisitas menunjukkan terjadinya perbedaan varian antara residual suatu pengamatan dengan pengamatan lain. Untuk mendeteksi heteroskedastisitas digunakan scatter plot antara ZPRED dan SRESID. Jika titik-titik pada scatter plot tidak membentuk pola tertentu, serta menyebar di atas dan dibawah angka nol sumbu $\mathrm{Y}$, maka tidak ada heteroskedastisitas dalam model regresi. Berikut adalah scatter plot yang dihasilkan model regresi :

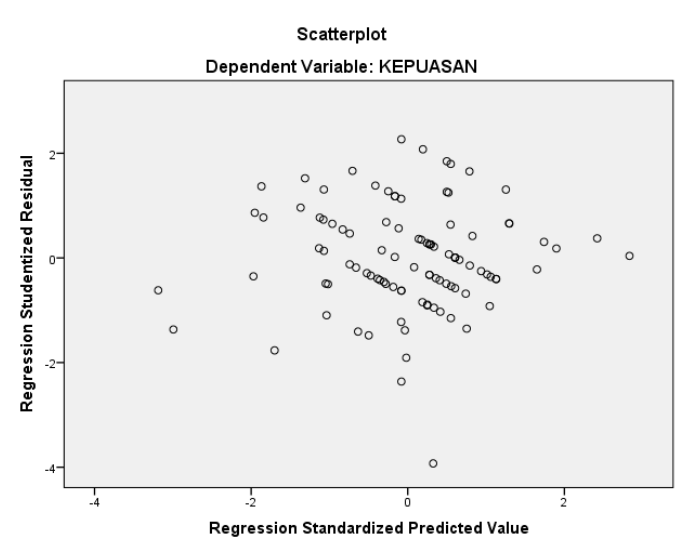

Gambar 2. Scatter Plot

Sumber : Hasil Penelitian,2019 (data diolah)

Gambar 2. menunjukkan bahwa titiktitik pada scatter plot tidak membentuk pola tertentu, serta menyebar di atas dan di bawah angka nol sumbu Y. sehingga dapat disimpulkan tidak ada heteroskedastisitas dalam model regresi.

\subsection{Analisis Regresi Linier Berganda}

Analisis regresi linier berganda digunakan untuk mengetahui ada tidaknya pengaruh keandalan, daya tanggap, jaminan, perhatian dan Bukti fisik terhadap kepuasan masyarakat dalam menggunakan pelayanan publik dalam layanan pertanahan.

Tabel 5. Hasil Uji Analisis Regresi Linier Berganda

\begin{tabular}{|c|c|c|c|c|c|c|}
\hline \multicolumn{7}{|c|}{ Coefficients $^{a}$} \\
\hline \multirow{2}{*}{\multicolumn{2}{|c|}{ Model }} & \multicolumn{2}{|c|}{$\begin{array}{c}\text { Unstandardiz } \\
\text { ed } \\
\text { Coefficients }\end{array}$} & \multirow{2}{*}{$\begin{array}{c}\begin{array}{c}\text { Standar } \\
\text { dized }\end{array} \\
\text { Coeffici } \\
\text { ents }\end{array}$} & \multirow[b]{2}{*}{ t } & \multirow[b]{2}{*}{ Sig. } \\
\hline & & $\mathrm{B}$ & Error & & & \\
\hline & (Constant) & 5.664 & 2.238 & & 2.531 & .013 \\
\hline & Keandalan & .075 & .180 & .048 & .417 & .677 \\
\hline & $\begin{array}{l}\text { Daya } \\
\text { Tanggap }\end{array}$ & .292 & .143 & .252 & 2.047 & .043 \\
\hline & Jaminan & .110 & .164 & .076 & .669 & .505 \\
\hline & Perhatian & .431 & .199 & .240 & 2.168 & .033 \\
\hline & Bukti Fisik & .182 & .143 & .132 & 1.270 & .207 \\
\hline
\end{tabular}

Sumber : Hasil Penelitian,2019 (data diolah) 
Berdasarkan hasil pengolahan data di atas dapat disusun persamaan regresi sebagai berikut:

$\mathrm{Y}=5,664+0,075 \mathrm{X}_{1}+0,292 \mathrm{X}_{2}+0,110 \mathrm{X}_{3}+$ $0,431 \mathrm{X}_{4}+0,182 \mathrm{X}_{5}$

Dari hasil persamaan di atas, maka dapat diintepretasikan sebagai berikut:

1. Konstanta sebesar 5,664, artinya jika tidak ada variable Keandalan, Daya Tanggap, Jaminan, Perhatian, dan Bukti fisikmaka variable independen sebesar 5,664.

2. Koefisien regresi keandalan adalah 0,075, artinya setiap kenaikan keandalan sebesar 1 poin, maka DPR akan meningkat sebesar 0,075.

3. Koefisien regresi daya tanggap adalah 0,292 , artinya setiap kenaikan daya tanggap sebesar 1 poin, maka DPR akan meningkat sebesar 0,292.

4. Koefisien regresi jaminan adalah 0,110 , artinya setiap kenaikan jaminan sebesar 1 poin, maka jaminan akan meningkat sebesar 0,110 .

5. Koefisien regresi perhatian adalah 0,431, artinya setiap kenaikan perhatian sebesar 1 poin, maka perhatian akan meningkat sebesar 0,431 .

6. Koefisien regresi bukti fisik adalah 0,182 , artinya setiap kenaikan bukti fisik sebesar 1 poin, maka bukti fisik akan meningkat sebesar 0,182

\subsection{Uji Signifikansi Parsial (Uji t)}

Uji $t$ diguakan untuk mengetahui variabel independen secara parsial berpengaruh terhadap variabel dependen. Dasar pengambilan keputusan (Ghozali, 2005:84) adalah dengan menggunakan angka probabilitas signifikansi, yaitu :

a. Apabila angka probabilitas signifikani $>$ 0.1, maka Ho diterima danHa ditolak.

b. Apabila angka probabilitas signifikansi $<$ 0.1, maka Ho ditolak dan $\mathrm{Ha}$ diterima.
Tabel 6. Hasil Uji Signifikansi Parsial (Uji t)

\begin{tabular}{|c|c|c|c|c|c|c|}
\hline $\begin{array}{c}\text { Variabel } \\
\text { Kualitas } \\
\text { Pelayanan }\end{array}$ & $\begin{array}{c}\text { Variabel } \\
\mathbf{Y}\end{array}$ & $\begin{array}{c}\mathrm{T} \\
\text { table }\end{array}$ & $\begin{array}{c}\mathrm{T} \\
\text { hitung }\end{array}$ & $\begin{array}{l}\text { Sig. } \\
\text { tabel }\end{array}$ & $\begin{array}{c}\text { Sig } \\
\text { hitung }\end{array}$ & Hipotesis \\
\hline Keandalan & \multirow{5}{*}{$\begin{array}{l}\text { Kepuasan } \\
\text { Masyrakat }\end{array}$} & 1.290 & 0.417 & 0.1 & \begin{tabular}{|l|}
0.677 \\
\end{tabular} & $\begin{array}{c}\text { Terima H0, } \\
\text { Tolak Ha }\end{array}$ \\
\hline $\begin{array}{c}\text { Daya } \\
\text { Tanggap }\end{array}$ & & 1.290 & 2.047 & 0.1 & 0.043 & $\begin{array}{l}\text { Tolak HO, } \\
\text { Terima Ha }\end{array}$ \\
\hline Jaminan & & 1.290 & 0.669 & 0.1 & 0.505 & $\begin{array}{c}\text { Terima Ho, } \\
\text { Tolak Ha }\end{array}$ \\
\hline Perhatian & & 1.290 & 2.168 & 0.1 & 0.033 & $\begin{array}{c}\text { Tolak H0, } \\
\text { Terima } \mathrm{Ha}\end{array}$ \\
\hline Bukti fisik & & 1.290 & 1.270 & 0.1 & 0.207 & $\begin{array}{c}\text { Terima H0, } \\
\text { Tolak Ha }\end{array}$ \\
\hline
\end{tabular}

a. Pengaruh keandalan terhadap kepuasan $\rightarrow$ Berdasarkan hasil di atas, terlihat bahwa nilai t hitung lebih kecil dari t table dan Sig. dari keandalan adalah 0,667 atau lebih dari 0,1. Berdasarkan hasil tersebut, maka dapat dinyatakan bahwa keandalan tidak berpengaruh terhadap kepuasan masyarakat.

b. Pengaruh daya tanggap terhadap kepuasan $\rightarrow$ Berdasarkan hasil di atas, terlihat bahwa nilai t hitung lebih besar terhadap $t$ tabel dan nilai Sig. dari daya tanggap adalah 0.043 atau kurang dari 0,1 . Berdasarkan hasil tersebut, maka dapat dinyatakan bahwa daya tanggap berpengaruh terhadap kepuasan masyarakat.

c. Pengaruh jaminan terhadap kepuasan $\rightarrow$ Berdasarkan hasil di atas, terlihat bahwa nilai $t$ hitung lebih besar terhadap $\mathrm{t}$ tabel dan nilai Sig. dari jaminan adalah 0,505 atau kurang dari 0,1 . Berdasarkan hasil tersebut, maka dapat dinyatakan bahwa jaminan tidak berpengaruh terhadap kepuasan masyarakat.

d. Pengaruh perhatian terhadap kepuasan $\rightarrow$ Berdasarkan hasil di atas, terlihat bahwa nilai $t$ hitung lebih besar terhadap $\mathrm{t}$ tabel dan nilai Sig. dari perhatian adalah 0,033 atau kurang dari 0,1. Berdasarkan hasil tersebut, maka dapat dinyatakan bahwa 
perhatian berpengaruh terhadap kepuasan masyarakat.

e. Pengaruh bukti fisik terhadap kepuasan $\rightarrow$ Berdasarkan hasil di atas, terlihat bahwa nilai t hitung lebih kecil dari $\mathrm{t}$ table dan Sig. dari bukti fisik adalah 0,207 atau lebih dari 0,1. Berdasarkan hasil tersebut, maka dapat dinyatakan bahwa bukti fisik tidak berpengaruh terhadap kepuasan masyrakat.

\subsection{Uji Signifikansi Silmutan (Uji F)}

Uji $\mathrm{F}$ digunakan untuk mengetahui apakah semua variabel bebas secara bersama-sama dapat berpengaruh terhadap variabel terikat. Pengujian ini dilakukan dengan membandingkan nilai $\mathrm{F}$ hitung dengan nilai $\mathrm{F}$ tabel. Jika nilai $\mathrm{F}$ hitung lebih besar dari nilai $\mathrm{F}$ tabel, maka Ho ditolak, artinya variabel independen

secara bersama-sama mempengaruhi variabel dependen. Sedangkan jika nilai $\mathrm{F}$ hitung lebih kecil dari nilai $\mathrm{F}$ tabel, maka Ho diterima, artinya variabel independen tidak berpengaruh signifikan terhadap variabel dependen (Ali Muhson, 2015:30).

Tabel 7. Hasil Uji Signifikansi Silmutan (Uji F)

\begin{tabular}{|c|c|c|c|c|c|}
\hline \multicolumn{6}{|c|}{ ANOVA $^{a}$} \\
\hline Model & $\begin{array}{l}\text { Sum of } \\
\text { Squares }\end{array}$ & df & $\begin{array}{l}\text { Mean } \\
\text { Square }\end{array}$ & F & Sig. \\
\hline Regression & 173.403 & 5 & 34.681 & 11.479 & $.000^{\circ}$ \\
\hline Residual & 283.987 & 94 & 3.021 & & \\
\hline Total & 457.390 & 99 & 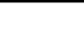 & & \\
\hline \multicolumn{6}{|c|}{ a. Dependent Variable: Kepuasan } \\
\hline
\end{tabular}

Sumber : Hasil Penelitian,2019 (data diolah)

Berdasarkan tabel di atas menunjukkan bahwa nilai $F_{\text {hitung }}$ sebesar 11,479 dan sig. sebesar 0,000 $(<0,1)$. Lebih besar daripada nilai $F_{\text {tabel }}$ yakni 2,67 , dengan tingkat kesalahan 10\% Maka variabel keandalan, daya tanggap, jaminan, perhatian, dan bukti fisik secara signifikan mempengaruhi variabel kepuasan masyarakat.

\subsection{Koefisien Determinasi}

Koefisien determinasi $\left(R^{2}\right)$ artinya mengukur seberapa jauh kemampuan model dalam menerangkan variasi variabel terikat. Nilai $R^{2}$ yang kecil berarti kemampuan variabel bebas dalam menjelaskan variabel terikat sangat terbatas. Nilai R2 yang mendekati 1 berarti kemampuan variabel bebas memberikan semua informasi yang dibutuhkan untuk memprediksi variasi variabel terikat secara simultan (Ali Muhson, 2015: 30).

\section{Tabel 8. Hasil Uji Koefisien Determinasi}

Sumber :Hasil Penelitian, 2019 (data diolah)

Koefisien determinasi pada penelitian ini menggunakan acuan Adjusted R Square dimana Nilai Adjusted $\mathrm{R}^{2}$ berkisar $0<\mathrm{R}^{2}<$ 1. Jika koefisien determinasi semakin mendekati 1 , artinya model yang digunakan semakin tepat.Karena sumbangan variabel bebas dikatakan sempurna apabila nilainya $=1$ yang ada besarnya adalah $100 \%$.

Berdasarkan tabel diatas dapat dijelaskan bahwa menunjukkan nilai Adjusted $\mathrm{R}^{2}$ sebesar 0,346. Hal ini berarti bahwa 0,346 $(34,6 \%)$ variabel kepuasan dapat dijelaskan oleh keandalan, daya

\begin{tabular}{|l|r|r|r|r|}
\hline \multicolumn{5}{|c|}{ Model Summary } \\
\hline $\begin{array}{l}\text { Mo } \\
\text { del }\end{array}$ & \multicolumn{1}{|c|}{$\mathrm{R}$} & R Square & $\begin{array}{c}\text { Adjusted R } \\
\text { Square }\end{array}$ & $\begin{array}{r}\text { Std. Error of } \\
\text { the Estimate }\end{array}$ \\
\hline 1 & $.616^{\text {a }}$ & .379 & .346 & 1.738 \\
\hline \multicolumn{3}{|l|}{$\begin{array}{l}\text { a. Predictors: (Constant), Bukti Fisik, Jaminan, } \\
\text { Keanalan, Perhatian, Daya Tanggap }\end{array}$} \\
\hline
\end{tabular}

tanggap, jaminan, perhatian, bukti fisik. Sisanya dijelaskan oleh variabel lain yang tidak dimasukkan kedalam model penelitian.

\section{KESIMPULAN DAN SARAN}




\subsection{Kesimpulan}

Berdasarkan pembahasan yang telah dilakukan sebelumnya, maka dapat diambil kesimpulan sebagai berikut :

1. Berdasarkan hasil uji $t$ variabel keandalan tidak berpengaruh terhadap kepuasan masyarakat.

2. Berdasarkan hasil uji t variabel daya tanggap berpengaruh terhadap kepuasan masyarakat.

3. Berdasarkan hasil dari uji t variabel jaminan tidak berpengaruh terhadap kepuasan masyarakat.

4. Berdasarkan hasil uji $t$ variabel perhatian berpengaruh terhadap kepuasan masyarakat.

5. Berdasarkan hasil uji t variabel bukti fisik tidak berpengaruh terhadap kepuasan masyarakat.

6. Berdasarkan hasil uji f Maka variabel keandalan, daya tanggap, jaminan, perhatian, dan bukti fisik secara signifikan mempengaruhi variabel kepuasan masyarakat.

\subsection{Saran}

Berdasarkan hasil penelitian yang telah diperoleh maka berikut adalah saran dari peneliti:

1. Mengingat daya tanggap dan perhatian mempunyai pengaruh yang paling mendominasi terhadap kepuasan masyarakat, maka sebaiknya kantor Pertanahan Kabupaten Bogor mempertahankan mutu dan lebih meningkatkan kualitas pelayanan loket pendaftaran tanah.

2. Untuk meningkatkan dimensi keandalan dalam kualitas pelayanan sebaiknya pegawai loket pendaftaran menguasai mengenai layanan pertanahan demi memberikan kepuasan masyarakat.

3. Untuk meningkatkan dimensi jaminan dalam kualitas pelayanan sebaiknya pegawai loket pendaftaran bertanggung jawa atas kepastian penyelesaian layanan pertanahan.
4. Untuk meningkatkan dimensi bukti fisik dalam kualitas pelayanan sebaiknya kondisi loket pendaftaran dijaga kebersihan dan kenyamanannya.

5. Karena keterbatasan peneliti, diharapkan penelitian ini dapat dijadikan referensi untuk penelitian sejenis lainnya, serta diharapkan untuk menambahkan variabel lain yang tidak disertakan pada penelitian ini.

\section{DAFTAR PUSTAKA}

Adam, M. (2015). Manajemen Pemasaran Jasa Teori dan Aplikasi. Bandung: Alfabeta.

Hadi, Sutrisno. 2015, Statistik. Pustaka Pelajar, Yogyakarta.

Kotler, Phillip dan Kevin L. Keller. (2016). Marketing Management 16 edition. New Jersey: Pearson.

Sinambela, P. (2008). Reformasi Pelayanan Publik: Teori Kebijakan dan Implementasi. Bumi Aksara: Jakarta

Sitomorang. S. H., \& Lufti, M. (2014). Teknik Analisis Data. Medan: USU Pres.

Sugiyono. 2012, Metode Penelitian Kuantitatif Kualitatif dan R\&D. Alfabeta, Bandung.

---------. 2014, Metode Penelitian Kuantitatif ,Alfabeta, Bandung

Tjiptono, Fandy dan Gregorius Candra. 2012, Pemasaran Strategik , Andi, Yogyakarta.

Tjiptono, Fandy. 2015. Strategi Pemasaran. Penerbit Andi,Yoggyakarta.

, $\mathrm{Cv}$ Andi Offset, Yogyakarta. 2016, Service, Quality

And Satisfaction. $\mathrm{Cv}$ Andi Offset Yogyakarta.

V Sujarweni,Wiratna. 2014, Metodologi Penelitian. PUSTAKA BARU PRESS, Yogyakarta.

Widya Arum Vellayati, 2018, Pengaruh Kualitas Pelayanan Publik Dan Disiplin Kerja Pegawai Terhadap 
Kepuasan Masyarakat Di Kantor

Balai Desa Rowosari Kecamatan

Ulujami Kabupaten Pemalang.

Universitas Negeri Yogyakarta,

Yogyakarta.

Yessy Gusti Eka Pratiwi. 2018 Pengaruh

Kualitas Pelayanan Terhadap

Kepuasan Masyarakat Sebagai Pasien

Di Puskesmas Sering Kecamatan

Medan Tembung.

Perundang-undangan :

Undang-Undang No 25 Tahun 2009

Tentang Pelayanan Publik.

Keputusan Menteri Pendayagunaan

Aparatur Negara (KEPMENPAN)

Nomor 25 Tahun 2004. 